\title{
Conversion of Ethanol-Lignin from Pine Wood in a Supercritical Ethanol in the Presence of Borate-Containing Alumina Catalysts
}

\author{
Victor I. Sharypov*a, Natalia G. Beregovtsova ${ }^{\text {a, }}$ \\ Sergei V. Baryshnikova, Angelina V. Miroshnikova ${ }^{a}$, \\ Alexandr V. Lavrenov ${ }^{b}$ and Boris N. Kuznetsov ${ }^{a, c}$ \\ anstitute of Chemistry and Chemical Technology SB RAS \\ FRC "Krasnoyarsk Science Center SB RAS" \\ 50/24 Akademgorodok, Krasnoyarsk, 660036, Russia \\ ${ }^{b}$ Institute of Hydrocarbons Processing SB RAS \\ 54 Neftezavodskaya, Omsk, 644040, Russia \\ 'Siberian Federal University \\ 79 Svobodny, Krasnoyarsk, 660041, Russia
}

The influence of temperature on the conversion of ethanol-lignin in supercritical ethanol and on the yield and composition of the products formed was studied. In the absence of catalysts, the highest yield (60 wt.\%) of liquid products of thermal conversion of ethanol-lignin was obtained at the temperature of $300{ }^{\circ} \mathrm{C}$. According to GC-MS data, the ethanol-soluble products mainly consist of phenols, methoxyphenols and ethyl esters of carboxylic acids. The increase of the temperature of ethanol-lignin conversion to $400{ }^{\circ} \mathrm{C}$ intensifies the transformation of liquid ethanol-soluble products into solid and gaseous substances and leads to a decrease in ethanol-soluble products the content of methoxyphenols by 3 times and of carboxylic acid esters by 2 times.

The use of catalysts, based on borate-containing alumina in the process of ethanol-lignin conversion in a supercritical ethanol at the temperature $300{ }^{\circ} \mathrm{C}$ increases the yield of products, boiling up to $180{ }^{\circ} \mathrm{C}$ by 3,4-3,6 times and rises the yield of methoxyphenols by 1,4-1,7 times in comparison with a non-catalytic process.

Keywords: pine ethanol-lignin, supercritical ethanol, conversion, borate-containing catalysts, liquid products, composition.

(C) Siberian Federal University. All rights reserved

* Corresponding author E-mail address: sharypov@icct.ru 
Citation: Sharypov V.I., Beregovtsova N.G., Baryshnikov S.V., Miroshnikova A.V., Lavrenov A.V., Kuznetsov B.N. Conversion of ethanol-lignin from pine wood in a supercritical ethanol in the presence of borate-containing alumina catalysts, J. Sib. Fed. Univ. Chem., 2018, 11(1), 81-92. DOI: 10.17516/1998-2836-0060.

\title{
Конверсия этаноллигнина древесины сосны \\ в среде сверхкритического этанола \\ в присутствии катализаторов \\ на основе боратсодержащего оксида алюминия
}

\begin{abstract}
В.И. Шарыпов ${ }^{a}$, Н.Г. Береговцова ${ }^{a}$, С.В. Барышников ${ }^{a}$, А.В. Мирошникова ${ }^{a}$, А.В. Лавренов ${ }^{\sigma}$, Б.Н. Кузнецов ${ }^{\text {a, }}$ ${ }^{a}$ Институт химии и химической технологии СО РАН ФИЦ «Красноярский научный центр СО РАН» Россия, 660036, Красноярск, Академгородок, 50/24 ${ }^{6}$ Институт проблем переработки углеводородов СО РАН Россия, 644040, Омск, ул. Нефтезаводская, 54 ${ }^{8}$ Сибирский федеральный университет Россия, 660041, Красноярск, пр. Свободный, 79
\end{abstract}

Изучено влияние температуры на конверсию этаноллигнина древесинь соснь $в$ сверхкритическом этаноле, на выход и состав образующихся продуктов. В отсутствии катализаторов максимальный выход жидких продуктов термопревращения этаноллигнина (60 мас. \%) получен при температуре $300{ }^{\circ}$ С. По данным хромато-масс-спектрометрии, растворимые в этаноле продукты представлены в основном фенолами, метоксифенолами и этиловыми эфирами карбоновых кислот. Повышение температуры конверсии этаноллигнина до $400{ }^{\circ} \mathrm{C}$ интенсифицирует превращение жидких продуктов в твердые и газообразнье вещеества и приводит к уменьшению содержания в жидких продуктах метоксифенолов в 3 раза и сложных эфиров карбоновых кислот в 2 раза.

Использование катализаторов на основе боратсодержащего оксида алюминия в прочессе конверсии этаноллигнина в сверхкритическом этаноле при $300{ }^{\circ} \mathrm{C}$ способствует увеличению выхода жидких продуктов, выкипающих до $180{ }^{\circ} \mathrm{C}$, в 3,4-3,6 раза и выхода метоксифенолов 8 1,4-1,7 раза по сравнению с некаталитическим проиессом.

Ключевые слова: этаноллигнин сосны, сверхкритическийэтанол, конверсия, боратсодержащие катализаторы, жидкие продукты, состав. 


\section{Введение}

В настоящее время лигнины, образующиеся в традиционных процессах переработки лигноцеллюлозного сырья, не находят широкого практического применения, хотя могут использоваться в качестве возобновляемого сырья для получения биотоплив и продуктов с высокой добавочной стоимостью [1]. Разрабатываемые новые процессы комплексной переработки лигноцеллюлозной биомассы предполагают фракционирование сырья на основные компоненты в качестве ключевой стадии [2-4]. С этой целью используются методы каталитического окисления лигноцеллюлозной биомассы кислородом [2], пероксидом водорода [3] и восстановление водородом [4], основанные на удалении лигнина из сырья. Известным методом выделения лигнина также является экстракция лигноцеллюлозного сырья легкокипящими органическими растворителями, либо их смесями с водой при температурах 180-200 ${ }^{\circ} \mathrm{C}$ [5-7]. Получаемые органосольвентные лигнины в отличие от традиционных технических не содержат серу, снижающую эффективность термокаталитической переработки и имеют высокую реакционную способность в интервале температур $250-350{ }^{\circ} \mathrm{C}$.

Дальнейшая трансформация органосольвентных лигнинов в химические соединения с низкой молекулярной массой может быть эффективно осуществлена методами термического превращения в среде низших алифатических спиртов, находящихся в сверхкритическом состоянии. В процессе терморастворения спирты не только экстрагируют продукты термической фрагментации лигнина, но и способны их алкилировать, предотвращая вторичные реакции конденсации продуктов [8]. Спирты могут служить источником активного водорода, что позволяет осуществлять реакции гидрирования и гидрогенолиза образующихся низкомолекулярных продуктов термопревращения лигнина [9]. Перспективным растворителем для этой цели является этанол [10-12]. Он не токсичен, относительно дешев и может быть получен из лигноцеллюлозного сырья в достаточном количестве с использованием существующих в настоящее время промышленных технологий.

Применение в качестве катализаторов высококремнеземных цеолитов или оксидов ряда металлов, нанесенных на кислотные подложки, позволяет интенсифицировать процессы деполимеризации лигнина с увеличением выхода жидких продуктов [13-16]. В современных процессах переработки нефтяного сырья широко применяют твердые кислотные и полифункциональные катализаторы на основе оксида алюминия, модифицированного кислородными соединениями бора $[17,18]$. Катализаторы на основе боратсодержащего оксида алюминия проявляют высокую стабильность в окислительных и восстановительных средах, легко регенерируются. Показано, что высокие значения величины удельной поверхности и объема пор для системы $\mathrm{B}_{2} \mathrm{O}_{3}-\mathrm{Al}_{2} \mathrm{O}_{3}$ достигаются при массовой доле $\mathrm{B}_{2} \mathrm{O}_{3} 20$ мас. \%, при этом количество кислотных центров возрастает в 1,7 раза, по сравнению с немодифицированным $\gamma-\mathrm{Al}_{2} \mathrm{O}_{3}[17]$.

В настоящей работе проведено исследование влияния температуры процесса и катализаторов на основе боратсодержащего оксида алюминия $\mathrm{B}_{2} \mathrm{O}_{3}-\mathrm{Al}_{2} \mathrm{O}_{3}$ (BA-20) и NiO/BA-20 на выход и состав продуктов, получаемых в процессе термопревращения этаноллигнина сосны в среде сверхкритического этанола. 


\section{Экспериментальная часть}

\section{Материаль}

Этаноллигнин выделяли из древесины сосны обыкновенной (Pinus sylvéstris), содержащей (\% в расчете на массу абсолютно сухой древесины): 47,6 - целлюлозы; 28,0 - лигнина; 16,5 гемицеллюлоз; 7,6 - экстрактивных веществ; 0,3 - золы. Воздушно-сухие опилки древесины сосны (влажность 3,6 мас. \%) измельчали на вибростенде ВР-2. Извлечение этаноллигнина из древесины сосны осуществляли экстракцией смесью этанол-вода и последующим осаждением холодной водой по методике [19]. Его выход составил 9,8 мас. \%, что соответствует 36,7 мас. \% от содержания лигнина Класона в исходной древесине сосны.

В качестве катализаторов были выбраны образцы боратсодержащего оксида алюминия $\mathrm{B}_{2} \mathrm{O}_{3}-\mathrm{Al}_{2} \mathrm{O}_{3}$ (BA-20) и никельсодержащего $\mathrm{B}_{2} \mathrm{O}_{3}-\mathrm{Al}_{2} \mathrm{O}_{3}(\mathrm{NiO} / \mathrm{BA}-20)$, синтезированные в Институте проблем переработки углеводородов СО РАН (г. Омск) [17]. Их состав и характеристики приведены в табл. 1.

\section{Термопревращение этаноллигнина сосны}

в сверхкритическом этаноле

Термическое превращение лигнина в сверхкритическом этаноле проводили в реакторе Autoclave Engineers (USA) объемом 100 мл. В реактор загружали 3 г лигнина, 0,3 г катализатора и 30 мл этанола. Затем реактор трижды продували инертным газом для удаления воздуха, устанавливали заданную температуру. Реакцию проводили при постоянном перемешивании в инертной атмосфере. В исследуемом интервале температур $250-400{ }^{\circ} \mathrm{C}$ рабочее давление в реакторе изменялось в зависимости от используемого катализатора от 6,3 до 7,6 МПа.

После окончания эксперимента газообразные продукты собирали в газометре и анализировали методом газовой хроматографии. Реактор количественно разгружали вымыванием этанолом, полученную смесь жидких и твердых продуктов разделяли фильтрованием. Твердый продукт экстрагировали этанолом до тех пор, пока растворитель не становился бесцветным, затем экстракт объединяли с фильтратом и отбирали аликвоту для исследования ее методом хромато-масс-спектрометрии (ГХ-МС). Этанол отгоняли, продукт доводили до постоянной массы сушкой под вакуумом (1 мм рт. ст.) при комнатной температуре и определяли выход жидких продуктов, кипящих выше $180{ }^{\circ} \mathrm{C}$ весовым методом. Выход жидких продуктов, кипящих до $180{ }^{\circ} \mathrm{C}$, определяли по разности между потерей веса древесины и суммарным весом

Таблица 1. Характеристики используемых катализаторов*

Table 1. Characteristics of the catalysts*

\begin{tabular}{|c|c|c|c|c|c|}
\hline Катализатор & $\begin{array}{c}\text { Состав } \\
\text { катализаторов, мас. \% }\end{array}$ & $\begin{array}{c}\mathrm{S}_{\text {уд.пов. }} \\
\mathrm{M}^{2} / \Gamma\end{array}$ & $\begin{array}{c}\mathrm{V}_{\Sigma}, \\
\mathrm{cm}^{3} / \Gamma\end{array}$ & $\begin{array}{c}\mathrm{V}_{\text {микро, }} \\
\mathrm{cm}^{3} / \Gamma\end{array}$ & $<\mathrm{d}>, \AA$ \\
\hline $\mathrm{BA-20}$ & $\mathrm{B}_{2} \mathrm{O}_{3} 18,8 ; \mathrm{Al}_{2} \mathrm{O}_{3} 81,2$ & 185 & 0,44 & 0,005 & 96 \\
\hline $\mathrm{NiO} / \mathrm{BA}-20$ & $\mathrm{NiO} 5,0$ & 167 & 0,35 & 0,006 & 85 \\
\hline
\end{tabular}

* $\mathrm{S}_{\text {удпов }}$ - площадь удельной поверхности по ВЕТ, $\mathrm{V}_{\Sigma}-$ суммарный объем пор, $\mathrm{V}_{\text {микро }}$ - объем микропор, $<\mathrm{d}>-$ средний размер пор. 
жидких продуктов, кипящих выше $180^{\circ} \mathrm{C}$ и газообразных продуктов. Выход твердого остатка определяли весовым методом после его высушивания под вакуумом (1 мм рт. ст.). Конверсию лигнина рассчитывали по формуле

$$
\text { конверсия лигнина }=\frac{\text { масса лигнина }(г)+\text { масса катализатора }(г)-\text { масса твердого остатка }(г)}{\text { органическая масса лигнина }(г)} \times 100 \% .
$$

\section{Исследование термических свойств этаноллигнина}

Термические свойства лигнина изучали с помощью синхронного термоанализатора STA-449C Jupiter, совмещенного с масс-спектрометром QMS 403C Aëolos. Применяли платина /платино-родиевый держатель (TG - DST сенсор типа S) в сочетании с корундовыми $\left(\mathrm{Al}_{2} \mathrm{O}_{3}\right)$ тиглями с проколотыми крышками. Образец массой $(8,5 \pm 0,2)$ мг подвергался нагреванию от 40 до $800{ }^{\circ} \mathrm{C}$ со скоростью $10^{\circ} \mathrm{C} /$ мин в динамической атмосфере аргона со скоростью потока 40 мл/мин.

Элементный состав этаноллигнина и твердых продуктов его термопревращения в сверхкритическом этаноле определяли с использованием анализатора HCNS-O EAFLASHTM 1112 фирмы «ThermoQuest».

Газообразные продукты анализировали на хроматографе «Кристалл-2000», снабженном детектором по теплопроводности. Разделение $\mathrm{CO}$ и $\mathrm{CH}_{4}$ осуществляли в изотермическом режиме при $60{ }^{\circ} \mathrm{C}$ на набивной колонке с цеолитом $\mathrm{NaX}$, разделение $\mathrm{CO}_{2}$ и углеводородов проводили на колонке Porapak QP.

Аликвотную часть жидких продуктов анализировали методом ГХ-МС с использованием хроматографа Agilent 7890A, снабженного детектором селективных масc Agilent 7000A Triple Quad, при регистрации полного ионного тока. Разделение продуктов осуществляли на капиллярной колонке HР-5MS при программировании температуры в интервале 40-250 ${ }^{\circ} \mathrm{C}$. Идентификацию проводили с использованием базы данных прибора NIST MS Search 2.0. Для количественного определения фенольных соединений в анализируемых продуктах была проведена калибровка хроматографа Agilent 7890A, снабженного детектором селективных мacc Agilent 7000A Triple Quad с использованием смесей стандартных соединений: фенол, гваякол, ванилин, сирингол, сиреневый альдегид. В качестве внутреннего стандарта применяли фенантрен.

\section{Результаты и обсуждение}

\section{Термоконверсия этаноллигнина сосньл}

в суперкритическом этаноле

Методом термогравиметрии установлено, что термическое разложение этаноллигнина сосны протекает в одну стадию, которая проявляется на дифференциальной кривой потери массы в виде интенсивного пика с максимумом при 403,7 ${ }^{\circ} \mathrm{C}$ (рис. 1). Скорость разложения лигнина в точке максимума кривой потери массы при $403,7{ }^{\circ} \mathrm{C}$ составляет 3,7 мас. \%/мин, степень конверсии - 40 мас. \% при $403,7{ }^{\circ} \mathrm{C}$ и 65 мас. \% при достижении температуры $800{ }^{\circ} \mathrm{C}$.

Влияние температуры процесса на показатели термических превращений этаноллигнина сосны в среде сверхкритического этанола без катализатора приведено на рис. 2. Максимальные

$$
-85-
$$




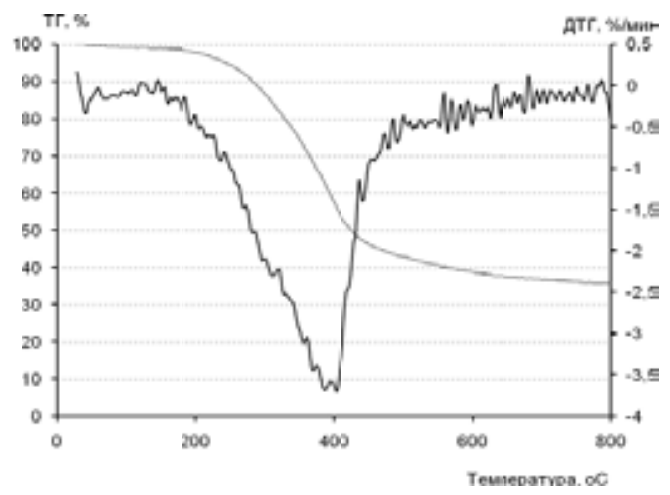

Рис. 1. Интегральная (ТГ) и дифференциальная (ДТГ) кривые потери массы этаноллигнина сосны

Fig. 1. Integral (TG) and differential (DTG) thermogravimetric curves of the weight loss of pine ethanol-lignin

Таблица 2. Влияние температуры процесса на выход газообразных продуктов конверсии этаноллигнина сосны

Table 2. The influence of the temperature on the yield of gaseous products of the pine ethanol-lignin conversion

\begin{tabular}{|c|c|c|c|c|}
\hline \multirow{2}{*}{ Температура, ${ }^{\circ} \mathrm{C}$} & \multicolumn{4}{|c|}{ Выход газообразных продуктов, мас. \% } \\
\cline { 2 - 5 } & $\mathrm{CO}$ & $\mathrm{CO}_{2}$ & $\mathrm{CH}_{4}$ & $\begin{array}{c}\text { Остальные углеводородные } \\
\text { газы* }\end{array}$ \\
\hline 250 & $<0,1$ & $<0,1$ & $<0,1$ & н.о** \\
\hline 300 & $<0,1$ & $<0,1$ & $<0,1$ & н.о \\
\hline 350 & 0,2 & 0,4 & 0,5 & 0,2 \\
\hline 400 & 1,0 & 0,8 & 0,6 & 4,6 \\
\hline
\end{tabular}

* - алканы и алкены $\mathrm{C}_{2}-\mathrm{C}_{4}$; ** - не обнаружено.

величины его конверсии в жидкие и газообразные продукты (70 мас. \%) и выхода этанолрастворимых продуктов (60 мас. \%) получены при $300{ }^{\circ} \mathrm{C}$. Подъем температуры до $400{ }^{\circ} \mathrm{C}$ сопровождается увеличением выхода газообразных продуктов, твердого остатка и снижением выхода этанолрастворимых продуктов. Одновременно в газообразных продуктах увеличивается выход оксидов углерода в $8-10$ раз, метана в 6 раз, углеводородных газов $\mathrm{C}_{2}-\mathrm{C}_{4}-$ в 4,6 раза (табл. 2).

В табл. 3 представлены результаты исследования элементного состава этаноллигнина сосны и твердых продуктов его термопревращения в среде сверхкритического этанола при варьировании температуры процесса. Как следует из полученных результатов, с ростом температуры в составе твердых продуктов увеличивается содержание углерода и уменьшается количество кислорода (табл. 3). Эти результаты показывают, что повышение температуры промотирует процессы карбонизации твердых продуктов.

По данным ГХ-МС (табл. 4), растворимые в этаноле продукты термопревращения этаноллигнина состоят из сложной смеси соединений, относящихся к различным классам органических веществ, представленных в основном фенолами, метоксифенолами, этиловыми эфирами

$$
-86-
$$


Таблица 3. Результаты элементного анализа этаноллигнина и твердых продуктов его конверсии в среде сверхкритического этанола, полученных при разных температурах процесса

Table 3. The results of ultimate analysis of the pine ethanol-lignin and solid products of its conversion in supercritical ethanol at the different temperatures

\begin{tabular}{|c|c|c|c|c|c|}
\hline \multirow{2}{*}{ Исследуемый продукт } & \multicolumn{2}{|c|}{ Содержание элементов, мас. \% } & \multicolumn{2}{|c|}{ Атомные отношения } \\
\cline { 2 - 6 } & $\mathrm{C}^{\mathrm{daf}}$ & $\mathrm{H}^{\mathrm{daf}}$ & $\mathrm{O}^{\mathrm{dif}}$ & $\mathrm{H} / \mathrm{C}$ & $\mathrm{O} / \mathrm{C}$ \\
\hline Исходный лигнин & 73,0 & 6,6 & 20,4 & 1,08 & 0,21 \\
\hline Твердый продукт, $250^{\circ} \mathrm{C}$ & 64,6 & 4,6 & 30,8 & 0,85 & 0,36 \\
\hline Твердый продукт, $300^{\circ} \mathrm{C}$ & 71,4 & 4,6 & 24,0 & 0,77 & 0,25 \\
\hline Твердый продукт, $350^{\circ} \mathrm{C}$ & 75,2 & 3,8 & 21,0 & 0,61 & 0,21 \\
\hline Твердый продукт, $400^{\circ} \mathrm{C}$ & 81,9 & 3,7 & 14,4 & 0,54 & 0,13 \\
\hline
\end{tabular}

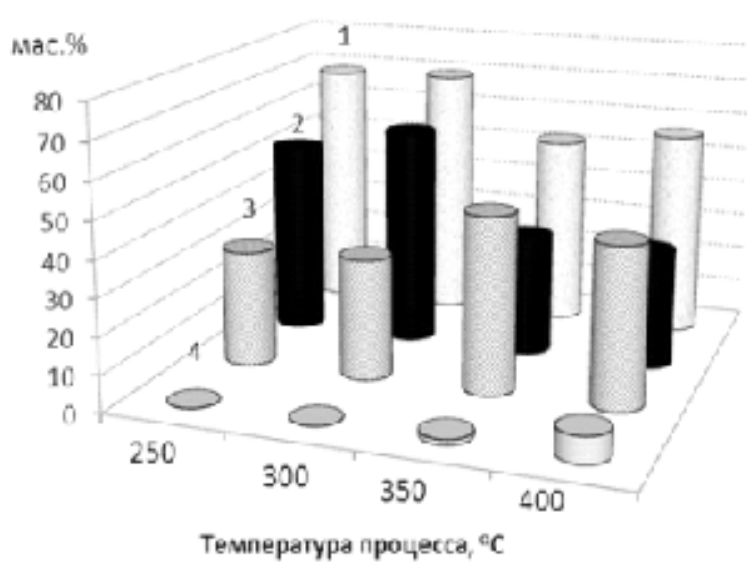

Рис. 2. Влияние температуры процесса термопревращения этаноллигнина сосны в сверхкритическом этаноле на конверсию (1), выход жидких этанолрастворимых (2), твердых (3) и газообразных продуктов превращения лигнина (4)

Fig. 2. The influence of the temperature on the conversion (1) and on the yield of ethanol-soluble liquids (2), solids (3), gaseous products (4) of the pine ethanol-lignin conversion in supercritical ethanol

карбоновых кислот и производными абиетиновой кислоты. Повышение температуры процесса термопревращения до $400{ }^{\circ} \mathrm{C}$ приводит к уменьшению содержания в них метоксифенолов в 3 раза и сложных эфиров карбоновых кислот в 2 раза.

\section{Влияние катализаторов на основе боратсодержащего оксида алюминия на конверсию этаноллигнина сосны в сверхкритическом этаноле}

Полученные результаты демонстрируют, что использование катализаторов на основе боратсодержащего оксида алюминия в процессе термического превращения этаноллигнина сосны при $300^{\circ} \mathrm{C}$ не оказывает значительного влияния на его конверсию (рис. 3). В их присутствии существенно снижается образование жидких продуктов, выкипающих выше $180{ }^{\circ} \mathrm{C}$, с 59 мас. \% в некаталитическом эксперименте до 45 и 48 мас. \% в опытах с BA-20 и NiO/BA-20, соответственно. Основной эффект заключается в резком увеличении в 3,4-3,6 раза выхода про- 
Таблица 4. Состав продуктов превращения этаноллигнина сосны в сверхкритическом этаноле при разных температурах (отн. \%)*

Table 4. Composition of products of the pine ethanol-lignin conversion in supercritical ethanol at the different temperatures (relative \%)*

\begin{tabular}{|c|c|c|c|c|c|}
\hline RT & Соединение & $250^{\circ} \mathrm{C}$ & $300^{\circ} \mathrm{C}$ & $350^{\circ} \mathrm{C}$ & $400{ }^{\circ} \mathrm{C}$ \\
\hline 15,279 & 1,4-диэтилбензол & 1,8 & $<0,1$ & 0,17 & 0,38 \\
\hline 17,665 & 4-метилфенол (р-крезол) & 0 & 0 & 0,5 & 2,6 \\
\hline 18,004 & 2-метоксифенол (гваякол) & 1,7 & 4,3 & 7,2 & 0,4 \\
\hline 20,209 & 3,4-диметилфенол & 0 & 0 & 1,8 & 6,2 \\
\hline 20,861 & 3-этилфенол & 0 & 0 & 0,3 & 2,6 \\
\hline 21,621 & 2-метокси-4-метилфенол (4-метилгваякол) & 7,2 & 8,9 & 11,2 & 0,6 \\
\hline 21,729 & этиловый эфир октановой кислоты & 0,4 & 0,5 & 0,8 & 0,6 \\
\hline 22,749 & 2-(1-метилэтил)-фенол & 0 & 0 & 0,1 & 2,4 \\
\hline 23,056 & 3-(1-метилэтил)-фенол & 0 & 0 & 0,6 & 1,2 \\
\hline 23,717 & 2,3,6-триметилфенол & 0 & 0 & 0,8 & 3,4 \\
\hline 24,215 & 2-метокси-4-этилфенол (4-этилгваякол) & 2,7 & 5,5 & 7,9 & 1,2 \\
\hline 24,688 & этиловый эфир нонановой кислоты & 0,3 & 0,2 & 1,5 & 2,3 \\
\hline 25,507 & 2-этил-4,5-диметилфенол & 0 & 0 & 0,3 & 0,9 \\
\hline 26,131 & не идентифицировано & 0 & 0 & 0 & 3,1 \\
\hline 26,695 & 2-метокси-4-пропилфенол (4-пропилгваякол) & 3,7 & 5,9 & 2,7 & $<0,1$ \\
\hline 30,574 & 4-(1,1-диметилэтил)1,2-бензолдиол & 0 & 0 & 0,34 & 1,7 \\
\hline 32,143 & диэтиловый эфир октандиовой кислоты (диэтилсуберат) & 1,0 & 0,7 & 0,6 & $<0,1$ \\
\hline 32,218 & $\begin{array}{l}\text { этиловый эфир 4-гидрокси-3-метокси бензойной кислоты } \\
\text { (этилваниллат) }\end{array}$ & 1,3 & 0,6 & 0 & 0 \\
\hline 33,704 & 4-гидрокси-3-метокси-бензол уксусная кислота & 1,6 & 0,9 & 0 & 0 \\
\hline 34,432 & не идентифицировано & 6,3 & 3,7 & 3,6 & 1,4 \\
\hline 40,887 & этиловый эфир гексадекановой кислоты & 4,6 & 2,9 & 2,8 & 1,9 \\
\hline 42,357 & 2,5-диметилфенантрен & 0 & 0 & 1,2 & 3,4 \\
\hline 42,812 & дегидро 4-эпиабиеталь & 1,2 & 0,4 & 0 & 0,9 \\
\hline 43,898 & этиловый эфир гептадекановой кислоты & 0,3 & 0,7 & 0,9 & 1,4 \\
\hline 45,39 & метиловый эфир 7,10,13-эйкозатриетиновой кислоты & 1,1 & 0 & 0 & 0 \\
\hline 46,441 & этиловый эфир 9,12-октадекадиеновой кислоты & 13,1 & 9,8 & 2,9 & 0,8 \\
\hline 47,565 & этиловый эфир октадекановой кислоты & 4,6 & 3,2 & 3,5 & 2,9 \\
\hline 48,283 & 1-метил-7-(1-метилэтил)фенантрен & 1,3 & 5,6 & 11,2 & 20,5 \\
\hline 53,476 & $\begin{array}{l}\text { 1-(7-гидрокси-5-метокси-2,2-диметил-2Н-бензопиран-6- } \\
\text { ил) этанон }\end{array}$ & 0 & 1,0 & 1,9 & 2,9 \\
\hline 54,348 & этилгомованиллат & 6,3 & 8,5 & 0,7 & $<0,1$ \\
\hline 55,358 & этиловый эфир дегидроабиетиновой кислоты & 16,5 & 23,7 & 9,4 & 2,4 \\
\hline 58,129 & не идентифицировано & 0 & 2 & 0,6 & 0,3 \\
\hline 62,772 & дегидроабиетиновая кислота & 3,7 & 1,3 & 0,3 & $<0,1$ \\
\hline
\end{tabular}

* - \% от суммы площадей всех пиков. 


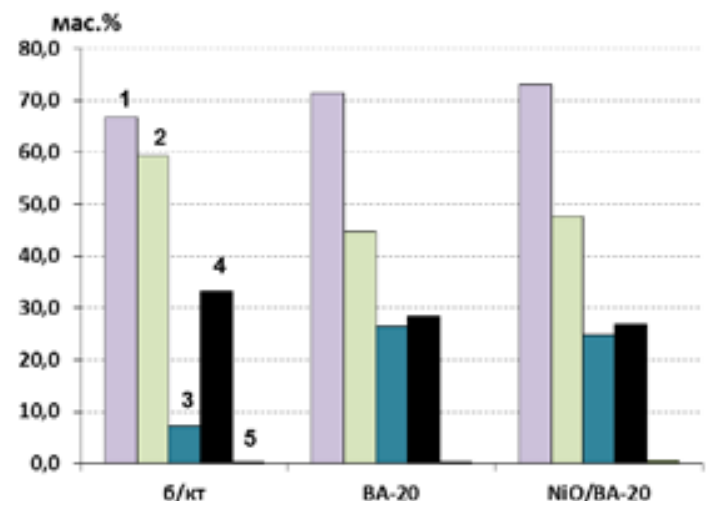

Рис. 3. Влияние катализаторов на конверсию (1) и выход жидких, выкипающих выше $180{ }^{\circ} \mathrm{C}$ (2), выкипающих до $180{ }^{\circ} \mathrm{C}$ (3), твердых (4) и газообразных (5) продуктов превращения этаноллигнина сосны в сверхкритическом этаноле при $300^{\circ} \mathrm{C}$

Fig. 3. The influence of the catalysts on the conversion (1) and the yield of the liquid products boiling above $180{ }^{\circ} \mathrm{C}(2)$, boiling up to $180{ }^{\circ} \mathrm{C} \mathrm{(3),} \mathrm{solids} \mathrm{(4)} \mathrm{and} \mathrm{gaseous} \mathrm{(5)} \mathrm{products} \mathrm{of} \mathrm{the} \mathrm{pine} \mathrm{ethanol-lignin} \mathrm{conversion} \mathrm{in}$ supercritical ethanol at $300{ }^{\circ} \mathrm{C}$

Таблица 5. Влияние катализаторов на состав фенольной фракции, полученной конверсией этаноллигнина сосны в сверхкритическом этаноле при $300{ }^{\circ} \mathrm{C}$

Table 5. The influence of the catalysts on the composition of the phenolic fraction of the pine ethanol-lignin conversion in supercritical ethanol in the presence of catalysts at $300{ }^{\circ} \mathrm{C}$

\begin{tabular}{|c|l|c|c|c|}
\hline \multirow{2}{*}{ RT } & \multicolumn{1}{|c|}{ Соединение } & \multicolumn{3}{|c|}{ Содержание, мас. $\%$} \\
\cline { 3 - 5 } & \multicolumn{1}{|c|}{ б/кт } & ВА-20 & NiO/BA-20 \\
\hline 18,004 & 2-метоксифенол (гваякол) & 0,74 & 1,49 & 0,95 \\
\hline 21,621 & $\begin{array}{l}\text { 2-метокси-4-метилфенол } \\
\text { (4-метилгваякол, р-креозол) }\end{array}$ & 1,54 & 2,34 & 2,08 \\
\hline 24,215 & 2-метокси-4-этилфенол (4-этилгваякол) & 0,95 & 1,87 & 1,59 \\
\hline 26,695 & 2-метокси-4-пропилфенол (4-пропилгваякол) & 1,04 & 2,33 & 2,08 \\
\hline 28,856 & 2-метокси-4-(1-пропенил) фенол (4-пропенилгваякол) & 0,03 & 0,04 & 0,22 \\
\hline 30,891 & 1-(4-гидрокси-3-метоксифенил)-2-пропанон (гваяцилацетон) & 0,10 & 0,24 & 0,21 \\
\hline 32,218 & $\begin{array}{l}\text { этиловый эфир 4-гидрокси-3-метокси бензойной кислоты (этил } \\
\text { ваниллат) }\end{array}$ & 0,08 & 0,44 & 0,28 \\
\hline 33,704 & 4-гидрокси-3-метокси-бензол уксусная кислота & 0,14 & 0,16 & 0,11 \\
\hline 54,348 & этил 4-гидрокси-3-метоксифенил ацетат (этилгомованиллат) & 1,53 & 1,63 & 1,21 \\
\hline & Суммарное содержание & 6,15 & 10,54 & 8,73 \\
\hline
\end{tabular}

дуктов, выкипающих до $180{ }^{\circ} \mathrm{C}$. В присутствии этих катализаторов выход газообразных продуктов из лигнина незначителен.

По данным количественного исследования растворимых в этаноле жидких продуктов термопревращения этаноллигнина сосны методом ГХ-МС, использование катализаторов на основе боратсодержащего оксида алюминия в процессе термопревращения этаноллигнина сосны приводит к увеличению содержания в них метоксифенолов в 1,4-1,7 
Таблица 6. Содержание мономерных метоксифенолов в составе фенольной фракции продуктов конверсии этаноллигнина сосны в сверхкритическом этаноле при $300{ }^{\circ} \mathrm{C}$ в присутствии катализатора BA-20

Table 6. The content of monomeric methoxyphenols in the phenolic fraction of the pine ethanol-lignin conversion products in supercritical ethanol at $300{ }^{\circ} \mathrm{C}$ in the presence of BA-20 catalyst

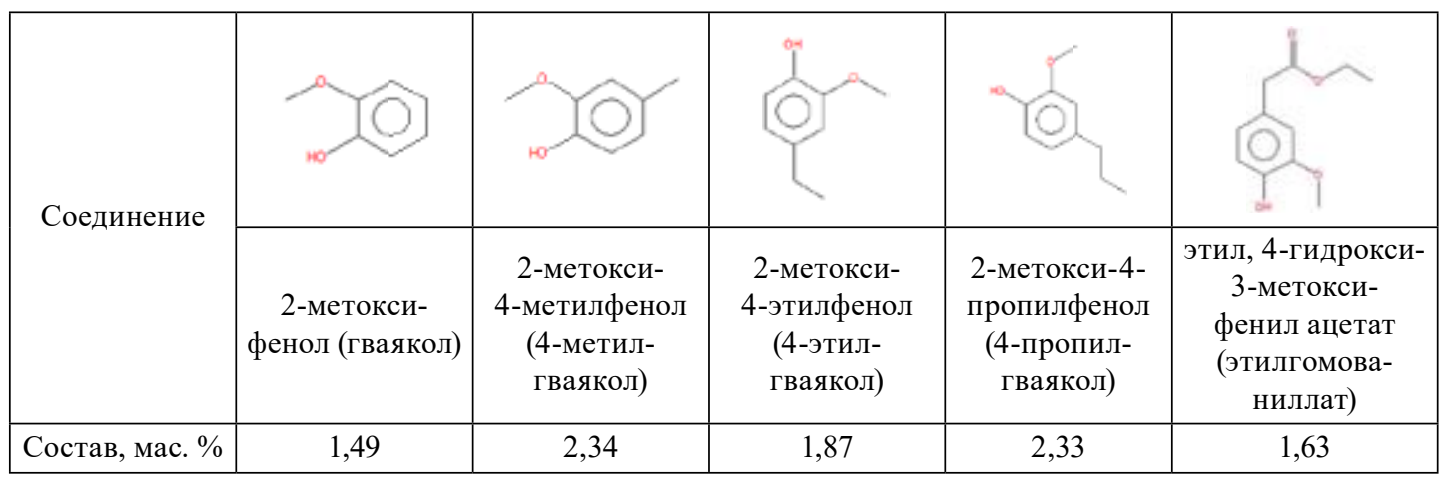

раза (табл. 5). Максимальный выход метоксифенолов получен в присутствии катализатора ВА-20 (табл. 6).

\section{Заключение}

Установлено, что в процессе конверсии этаноллигнина сосны в сверхкритическом этаноле в отсутствие катализаторов максимальный выход жидких продуктов, растворимых в этаноле, достигается при температуре $300^{\circ} \mathrm{C}$.

Растворимые в этаноле продукты превращения этаноллигнина при $300{ }^{\circ} \mathrm{C}$ представлены в основном фенолами, метоксифенолами и этиловыми эфирами карбоновых кислот. Повышение температуры конверсии этаноллигнина до $400{ }^{\circ} \mathrm{C}$ приводит к росту выхода твердых и газообразных продуктов, к снижению выхода этанолрастворимых продуктов и уменьшению относительного содержания в них метоксифенолов в 3 раза и сложных эфиров карбоновых кислот в 2 раза.

Использование катализаторов на основе боратсодержащего оксида алюминия в процессе термопревращения этаноллигнина сосны при температуре $300{ }^{\circ} \mathrm{C}$ приводит к увеличению в 3,4-3,6 раза выхода продуктов, выкипающих до $180^{\circ} \mathrm{C}$ и увеличению в 1,4-1,7 раза выхода метоксифенолов по сравнению с некаталитическим процессом.

Этаноллигнин сосны и жидкие продукты его конверсии в этаноле изучены с использованием приборов Красноярского регионального центра коллективного пользования ФИЦ КНЦ СО РАН.

\section{Список литературы}

1. Demirbas A. Progress and recent trends in biofuels. Prog. Energy Combust 2007. Vol. 33(1), P. $1-18$.

2. Tarabanko V.E., Kaygorodov K.L., Skiba E.A., Tarabanko N.E., Chelbina Y.V., Baybakova O.V., Kuznetsov B.N., Djakovitch L. Processing Pine Wood into Vanillin and Glucose

$$
-90-
$$


by Sequential Catalytic Oxidation and Enzymatic Hydrolysis. Journal of Wood Chemistry and Technology 2017. Vol. 37, P. 43-51.

3. Kuznetsov B.N., Chesnokov N.V., Yatsenkova O.V., Sharypov V.I., Garyntseva N.V., Ivanchenko N.M., Yakovlev V.A. Green catalytic valorization of hardwood biomass into valuable chemicals with the use of solid catalysts. Wood Sci. Technol 2017. Vol. 51, P. 1189-1208.

4. Van den Bosch S., Schutyser W., Vanholme R., Driessen T., Koelewijn S.-F., Renders T., De Meester B., Huijgen W.J.J., Dehaen W., Courtin C.M., Lagrain B., Boerjanbc W., SelsB.F. Reductive lignocellulose fractionation into soluble lignin-derived phenolic monomers and dimers and processable carbohydrate pulps. Energy Environ. Sci 2015. Vol. 8, P. 1748-1763.

5. Rabemanolontsoa H., Saka S. Various pretreatments of lignocellulosics. Bioresour. Technol 2016. Vol. 199, P. 83-91.

6. Zhang K., Pei Z., Wang D. Organic solvent pretreatment of lignocellulosic biomass for biofuels and biochemical: A review. Bioresour. Technol 2016. Vol. 199, P. 21-33.

7. Huijgen W.J.J., Smit A.T., De Wild P.J., Den Uil H. Fractionation of wheat straw by prehydrolysis, organosolv delignification and enzymatic hydrolysis for production of sugars and lignin. Bioresour. Technol 2012. Vol. 114, P. 389-398.

8. Kuznetsov B.N., Sharypov V.I., Chesnokov N.V., Beregovtsova N.G., Baryshnikov S.V., Lavrenov A.V., Vosmerikov A.V., Agabekov V.E. Lignin Conversion in Supercritical Ethanol in the Presence of Solid Acid Catalysts. Kinetika I Kataliz 2015. Vol. 56(4), P. 436-444.

9. Macala G.S., Matson T.D., Johnson C.L., Lewis R.S., Iretskii A.V., Ford P.C. Hydrogen transfer from supercritical methanol over a solid base catalyst: a model for lignin depolymerization. Chem. Sus. Chem 2009. Vol. 2, P. 215-217.

10. Kim J.Y., Oh Sh., Hwang H., Cho T., Choi I.-G., Choi J.W. Effects of various reaction parameters on solvolyticaldepolymerization of lignin in sub- and supercritical ethanol. Chemosphere 2013. Vol. 93, P. 1755-1764.

11. Løhre C., Barth T., Kleinert M. The effect of solvent and input material pretreatment on product yield and composition of bio-oils from lignin solvolysis. Journal of Analytical and Applied Pyrolysis 2016. Vol. 119, P. 208-216.

12. Huang X., Koranyi T.I., Boot M.D., Hensen E.J. Catalytic Depolymerization of Lignin in Supercritical Ethanol. Chem. Sus. Chem 2014. Vol. 7, P. 2276-2288.

13. Kim J.Y., Park J., Hwang H., Kim J.K., Song K., Choi J.W. Catalytic depolymerization of lignin macromolecule to alkylated phenols over various metal catalysts in supercritical tert-butanol. Journal of Analytical and Applied Pyrolysis 2015. Vol. 113, P. 99-106.

14. Wang H., Tucker M., Ji Y. Recent development in chemical depolymerization of lignin: A review. Journal of Applied Chemistry 2013. P. 1-9.

15. Шарыпов В.И., Береговцова Н.Г., Барышников С.В., Кузнецов Б.Н., Восмериков А.В., Таран О.П., Агабеков В.Е. Термическая конверсия лигнина древесины осины в этаноле в присутствии цеолитных катализаторов. Журнал Сибирского федерального университета. Химия 2013. T. 3(6), C. 241-250. [Sharypov V.I., Beregovtsova N.G., Baryshnikov S.V., Kuznetsov B.N., Vosmerikov A.V., Taran O.P., Agabekov V.E. Thermalconversion of aspen wood lignin in ethanol in the presence of zeolite catalysts. Journal of Siberian Federal University. Chemistry 2013. Vol. 3(6), P. 241-250. (InRuss.)] 
16. Шарыпов В.И., Береговцова Н.Г., Барышников С.В., Мирошникова А.В., Кузнецов Б.Н. Изучение состава и термических превращений этаноллигнина, выделенного из древесины осины. Журнал Сибирского федерального университета. Химия 2016. Т. 9(3), С. 296-307. [Sharypov V.I., Beregovtsova N.G., Baryshnikov S.V., Miroshnikova A.V., Kuznetsov B.N. Study of composition and thermal properties of ethanollignin isolated from aspen wood. Journal of Siberian Federal University. Chemistry 2016. Vol. 9(3), P. 296-307. (In Russ.)]

17. Лавренов А.В., Булучевский Е.А., Карпова Т.Р., Моисеенко М.А., Михайлова М.С., Чумаченко Ю.А., Скорплюк А.А., Гуляева Т.И., Арбузов А.Б., Леонтьева Н.Н., Дроздов В.А. Синтез, строение и свойства боратсодержащих оксидных катализаторов для процессов нефтехимии и синтеза компонентов моторных топлив. Химия в интересах устойчивого развития 2011. T. 19, C. 87-95. [Lavrenov A.V., Buluchevsky E.A., Karpova T.R., Moiseenko M.A., Mikhailova M.S., Chumachenko Yu.A., Skorplyuk A.A., Gulyaeva T.I., Arbuzov A.B.N., Leont'eva N.N., Drozdov V.A. Synthesis, structure and properties of borate-containing oxide catalysts for petrochemical processes and synthesis of motor fuel components. Chemistry for Sustainable Development 2011. Vol. 19, P. 8795. (In Russ.)]

18. Ламберов А.А., Ситникова Е.Ю., Гильмуллин Р.Р., Сидоров Н.А. Влияние добавки оксида бора на структуру и активность алюмоокидного катализатора скелетной изомеризации н-бутиленов. Катализ в промышиенности 2010. № 3, С. 55-62. [Lamberov A.A., Sitnikova E.Yu., Gilmullin R.R., Sidorov N.A. Effect of boron oxide additives on the structure and activity of alumina catalyst for skeletal isomerization of n-butylene. Catalysis in industry 2010. Vol. 3, P. 55-62. (In Russ.)]

19. Arato C., Kendall Pye E., Gjennestad G. The lignol approach to biorefining of woody biomass to produce ethanol and chemicals. Applied Biochemistry and Biotechnology 2005. Vol. 121-124, P. 871882. 